\title{
The Spectrum of Natural Frequencies of Acoustic Oscillations of a Spherical Quantum Dot with a Multilayer Shell
}

\author{
R. Peleshchak ${ }^{1,2}$, O. Kuzyk ${ }^{1}$, O. Dan'kivi,"* \\ ${ }^{1}$ Ivan Franko Drohobych State Pedagogical University, 24, Ivan Franko St., 82100 Drohobych, Ukraine \\ ${ }^{2}$ Lviv Polytechnic National University, 12, Stepan Bandera St., 79013 Lviv, Ukraine
}

(Received 02 July 2021; revised manuscript received 04 August 2021; published online 20 August 2021)

\begin{abstract}
A model that allows to determine the spectrum of acoustic oscillations of a spherical quantum dot (QD) of the core/multilayer shell type within the elastic continuum has been developed. The proposed model takes into account the dependence of elastic constants (acoustic wave velocities) on the geometric dimensions of the core of a QD and individual layers of its shell. Within the framework of the developed model, the spectrum of acoustic oscillations for QDs of the type of the InAs core with a single-layer GaAs shell and a double-layer $\mathrm{GaAs} / \mathrm{In}_{0.4} \mathrm{Ga}_{0.6} \mathrm{As}$ shell is calculated. It is established that the presence of a shell in a $\mathrm{QD}$ leads to a significant decrease in the natural frequencies of acoustic oscillations. It is shown that an increase in the number of shell nanolayers leads to a decrease in the degree of correlation between the frequencies of acoustic oscillations and the radius of the QD core. This is explained by the fact that frequencies of oscillations are mainly determined by two competing factors: the dependence of the frequency of oscillations on the $\mathrm{QD}$ radius and the dependence of the propagation velocities of longitudinal and transverse oscillations in thin layers on their thicknesses. The first factor contributes to a decrease in the frequency with increasing QD radius, and the second factor contributes to a decrease in the frequency with a decrease in the number of atoms in nanolayers (a decrease in their thickness).
\end{abstract}

Keywords: Core/shell quantum dot, Acoustic wave, Frequency of acoustic oscillations, Deformation.

\section{INTRODUCTION}

Semiconductor nanoheterostructures with quantum dots (QDs) have a high quantum yield of photoluminescence and are promising materials for creating heterolasers [1-3], solar cells [4-6] or use in medicine [7, 8]. However, QDs have a high density of surface defects (traps) due to the high ratio of surface area to volume, which act as centers of non-radiative recombination of carriers in QDs. Thus, they impair the overall performance of solar cells [4], reducing the intensity of photoluminescence due to the transfer of electric charge from a QD to an organic molecule [7]. One way to solve this problem is to create QDs with a protective shell that contains one or more layers (so-called core/shell QDs).

Passivation of the QD surface due to the use of shells of different materials proved to be an effective approach to reduce surface defects, which can expand the absorption spectrum, accelerate the transfer of current carriers, and reduce recombination losses. A special positive effect can be achieved if you use a multilayer shell. In particular, it was shown in [7] that shells of CdSe-core QDs, which have a multicomponent structure of $\mathrm{ZnS} / \mathrm{CdS} / \mathrm{ZnS}$, at a small thickness, much better suppress the reduction of the quantum yield of photoluminescence of QDs compared to both thin and thick ZnS shells. Therefore, core/multicomponent shell QDs can become optimal photoluminescent labels when creating systems for the diagnosis and treatment of cancer. In [4], it was shown that the correct choice of the shell allows to significantly increase the efficiency of solar cells based on core/shell QDs.

It should also be noted that QDs are sensitive to deformation [9], in particular, to the influence of acoustic waves. Acoustic deformation can occur, for example, under the influence of ultrasound [10] or photoacoustic effect (light radiation can lead to the generation of sound by a nanocluster) [11,12]. Such acoustic deformation due to the deformation potential can significantly change the energy spectrum of QDs [13]. Therefore, it is obvious that for predictable control of the parameters of optoelectronic devices based on core/shell QDs, information on the spectrum of natural acoustic oscillations of such nanosystems is important.

In this work, a model that allows to determine the spectrum of acoustic oscillations of a spherical QD of the core/multilayer shell type is developed. When determining the frequencies of acoustic oscillations, the essential parameters are the propagation velocities of longitudinal and transverse waves, which depend on the elastic constants of materials. The proposed model takes into account the dimensional dependence of elastic constants.

\section{THE MODEL}

Let us consider a spherical QD of the core/multilayer shell type (see Fig. 1) with a core radius $R_{0}$ and a thickness of the $i$-th layer of the shell $d_{i}=R_{i}-R_{i-1}$ (here $i=1,2, \ldots, n$ ).

The components of the displacement vector of the $j$-th atom of the QD core and shell layers $\mathbf{u}_{\mathrm{j}}^{(\mathrm{i})}(t, \mathbf{r})$ are found taking into account the fact that the displacement of each atom can be decomposed into a series due to the displacement of atoms $\mathbf{u}^{(\mathrm{i})}(\mathbf{r}, t)$ in the continuous approximation [14]:

\footnotetext{
*dankivolesya@ukr.net
} 


$$
\mathbf{u}_{\mathrm{j}}^{(\mathrm{i})}(t, \mathbf{r})-\mathbf{u}_{0} \propto\left(\mathbf{\rho}_{\mathrm{j}} \nabla\right) \mathbf{u}^{(\mathrm{i})}(\mathbf{r}, t),
$$

where $\boldsymbol{\rho}_{\mathrm{j}}$ is the radius-vector of the nearest neighbors; $\mathbf{u}_{\mathbf{0}}$ is the displacement vector of the central atom.

Let us choose a spherical coordinate system with the origin at the center of the QD. For radial oscillations, the displacement vector depends on only one coordinate $r$ and time $t$. Therefore, the following condition is met:

$$
\operatorname{rot} \mathbf{u}^{(\mathrm{i})}(t, \mathbf{r})=0 .
$$

Going to the scalar potential $\mathbf{u}^{(\mathrm{i})}(t, \mathbf{r})=\nabla \varphi^{(i)}$, equation (2) can be written in the form:

$$
\Delta \varphi^{(i)}=\frac{1}{c_{l}^{(i) 2}} \frac{\partial^{2} \varphi^{(i)}}{\partial t^{2}},
$$

where $c_{l}^{(i)}$ are the propagation velocities of longitudinal acoustic waves in the materials of the QD core and the shell layers. form:

We will look for a solution of these equations in the

$$
\varphi^{(i)}(r, t)=\frac{\chi^{(i)}(r)}{r} e^{-\mathbf{i} \omega t},(i=0,1,2, \ldots, n) .
$$

Taking into account the finiteness of the displacement in the center of the QD (at the point $r=0$ ) for the materials of the QD core $(i=0)$ and the shell layers $(i=1,2, \ldots, n)$, the solution of equations (3) has the form:

$$
\begin{gathered}
\varphi^{(0)}(r)=\frac{A^{(0)} \sin k^{(0)} r}{r} \mathrm{e}^{-\mathrm{i} \omega t}, \\
\varphi^{(i)}(r)=\left(\frac{A^{(i)} \sin k^{(i)} r}{r}+\frac{B^{(i)} \cos k^{(i)} r}{r}\right) \mathrm{e}^{-\mathrm{i} \omega t},
\end{gathered}
$$

where $k^{(i)}=\frac{\omega}{c_{l}^{(i)}}$.

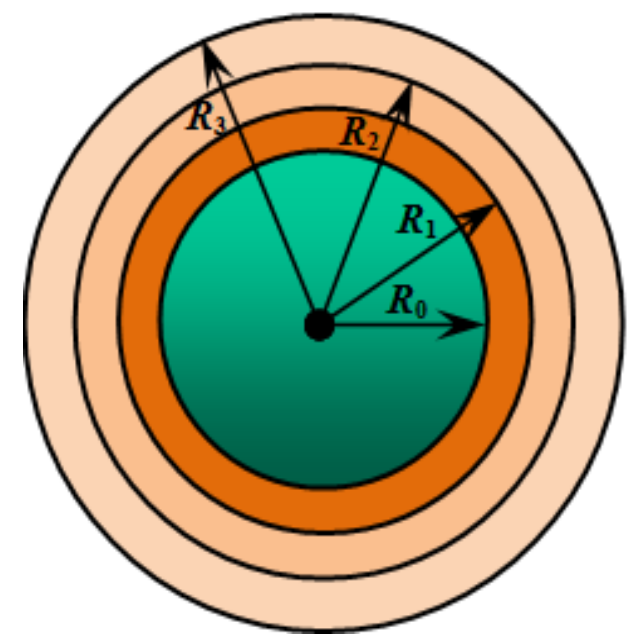

Fig. 1 - The geometric model of the core/multilayer shell QD
Since we consider a spherically symmetric system, i.e., the displacement vector has only a radial component $u_{r}$, the radial stress will be represented as:

$$
\begin{aligned}
\sigma_{r r}^{(i)} & =\rho^{(i)}\left(c_{l}^{(i) 2} \frac{\partial u_{r}^{(i)}}{\partial r}+2\left(c_{l}^{(i) 2}-2 c_{T}^{(i) 2}\right) \frac{u_{r}^{(i)}}{r}\right)= \\
& =\rho^{(i)}\left(c_{l}^{(i) 2} \Delta \varphi^{(i)}-4 c_{T}^{(i) 2} \frac{\partial \varphi^{(i)}}{\partial r} \frac{1}{r}\right),
\end{aligned}
$$

where $c_{T}^{(i)}$ are the propagation velocities of transverse acoustic waves in the materials of the $\mathrm{QD}$ core and the shell layers.

At the boundaries between the QD core and the shell, as well as between the individual layers of the shell, the conditions of equality of mechanical stresses and displacements must be met, and also the condition $\sigma_{r r}\left(R_{n}\right)=0$ must be fulfilled:

$$
\left\{\begin{array}{l}
\sigma_{r r}^{(i-1)}\left(R_{i-1}\right)=\sigma_{r r}^{(i)}\left(R_{i-1}\right) \\
u_{r}^{(i-1)}\left(R_{i-1}\right)=u_{r}^{(i)}\left(R_{i-1}\right) \\
\sigma_{r r}^{(n)}\left(R_{n}\right)=0 .
\end{array}\right.
$$

In addition, the condition of quantization of acoustic phonon modes must be satisfied [15]:

$$
\frac{1}{V} \int_{V} u_{r}^{*} u_{r} d V=\frac{\hbar}{2 M \omega},
$$

where $V$ and $M$ are the volume and mass of the core/ shell $\mathrm{QD}$, respectively; $\omega$ is the frequency of the corresponding mode of acoustic oscillations.

System (8) is a system of $2 n+1$ linear uniform algebraic equations with respect to unknowns $A^{(i)}, B^{(i)}$. The spectrum of natural frequencies of acoustic oscillations of the core/multilayer shell QD is found from the condition of non-triviality of the solutions of this system, i.e., equality to zero of the determinant composed of coefficients close to unknowns.

It is easy to show that in the case of a single-layer shell QD, the spectrum of acoustic oscillations is determined from the transcendental equation:

$$
\begin{aligned}
& \frac{\rho^{(0)}}{\rho^{(1)}} a^{(0)}\left(R_{0}\right)\left(c^{(1)} b^{(1)}\left(R_{1}\right)+a^{(1)}\left(R_{1}\right) d^{(1)}\right)= \\
& =c^{(0)}\left(a^{(1)}\left(R_{1}\right) b^{(1)}\left(R_{0}\right)+a^{(1)}\left(R_{0}\right) b^{(1)}\left(R_{1}\right)\right),
\end{aligned}
$$

where $a^{(i)}\left(R_{i}\right)=\left(\frac{4 c_{T}^{(i) 2}}{R_{i}^{2}}-\omega^{2}\right) \times$

$$
\begin{aligned}
& \times \sin k^{(i)} R_{i}-4 c_{T}^{(i) 2} k^{(0)} \frac{\cos k^{(i)} R_{i}}{R_{i}} ; b^{(1)}\left(R_{i}\right)= \\
& =\left(\frac{4 c_{T}^{(1) 2}}{R_{i}^{2}}-\omega^{2}\right) \cos k_{1} R_{i}+4 c_{T}^{(1) 2} k_{0} \frac{\sin k^{(1)} R_{i}}{R_{i}} ; \\
& \quad c^{(i)}=k^{(i)} \frac{\cos k^{(i)} R_{0}}{R_{0}}-\frac{\sin k^{(i)} R_{0}}{R_{0}^{2}} ;
\end{aligned}
$$




$$
d^{(1)}=k^{(1)} \frac{\sin k^{(1)} R_{0}}{R_{0}}+\frac{\cos k^{(1)} R_{0}}{R_{0}^{2}} .
$$

It is seen from the above formulas that the important parameters that determine the spectrum of acoustic oscillations of the core/shell QD are the propagation velocities of longitudinal and transverse waves, and, consequently, the elastic constants of materials. In turn, the elastic constants of materials can significantly change their values with decreasing crystal size [16].

When calculating the velocities of sound in the QD core and shell nanolayers, the method of determining Young's modulus and Poisson's ratio as a function of temperature and the number of atoms in the layer (depending on the core radius $R_{0}$ and the thickness of the corresponding shell layer $d_{\mathrm{i}}$ ) proposed in [16], was used, where the change in the elastic moduli with a decrease in the number of atoms is explained by an increase in the surface pressure:

$$
\begin{gathered}
c_{l}^{(i)}=\sqrt{\frac{E^{(i)}\left(d_{i}\right)\left(1-v^{(i)}\left(d_{i}\right)\right)}{\rho^{(i)}\left(1+v^{(i)}\left(d_{i}\right)\right)\left(1-2 v^{(i)}\left(d_{i}\right)\right)}}, \\
c_{T}^{(i)}=\sqrt{\frac{E^{(i)}\left(d_{i}\right)}{2 \rho^{i}\left(1+v^{(i)}\left(d_{i}\right)\right)}} .
\end{gathered}
$$

\section{CALCULATIONS, RESULTS AND DISCUSSION}

The calculations of natural frequencies of acoustic oscillations of the core/shell spherical QD were performed for InAs QDs with a single-layer GaAs shell and a two-layer GaAs/ $\mathrm{In}_{0.4} \mathrm{Ga}{ }_{0.6} \mathrm{As}$ shell at the following values of the parameters of bulk materials: $\rho^{(0)}=5680 \mathrm{~kg} / \mathrm{m}^{3}, \quad \rho^{(1)}=5320 \mathrm{~kg} / \mathrm{m}^{3}, \quad v^{(0)}=0.352 ，$ $v^{(1)}=0.318, \quad E^{(0)}=0.514 \mathrm{Mbar}, \quad E^{(1)}=0.869 \mathrm{Mbar}$, $T=300 \mathrm{~K}$. For the $\mathrm{In}_{0.4} \mathrm{Ga}{ }_{0.6}$ As layer, the parameters were calculated according to Vegard's rule.

Fig. 2 shows the dependences of the natural frequencies of the 0th (Fig. 2a) and 1st (Fig. 2b) modes of acoustic oscillations of a spherical $\mathrm{QD}$ of the type of InAs core/GaAs shell on the radius of the $\mathrm{QD}$ core at different values of the shell thickness. Such dependences are monotonically decreasing. Also, from Fig. 2 we see that the presence of the shell in the QD leads to a significant reduction in the natural frequencies of acoustic oscillations. This effect is especially well manifested for QDs of smaller size. In particular, the presence of a $3 \mathrm{~nm}$ thick shell in a $\mathrm{QD}$ with a core radius of $3 \mathrm{~nm}$ reduces the natural frequency of acoustic oscillations by $45 \%$. And in the case of a QD with a core radius of $10 \mathrm{~nm}$, such a decrease in the natural frequency is only $18 \%$. An increase in the shell thickness also leads to a decrease in the natural frequencies of acoustic oscillations, but at large radii of the $\mathrm{QD}$ core $\left(R_{0}>8 \mathrm{~nm}\right)$ such an effect is not significant.

Fig. 3 shows the dependences of the natural frequencies of the 0th (Fig. 3a) and 1st (Fig. 3b) modes of acoustic oscillations of a spherical QD of the type of InAs core/GaAs/In0.4Ga0.6As shell on the radius of the $\mathrm{QD}$ core at different thicknesses of the individual shell layers.
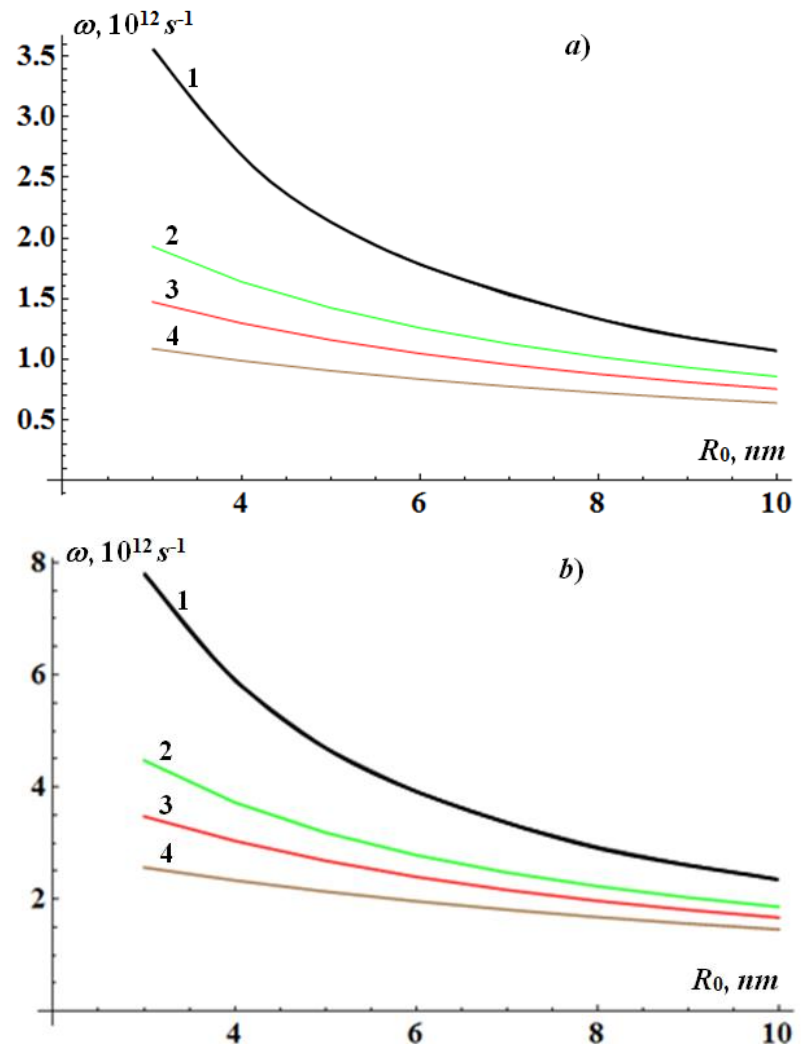

Fig. 2 - The dependences of the natural frequencies of acoustic oscillations of a QD of the type of InAs core/GaAs shell on the radius of the QD core for the 0th (a) and 1st (b) modes for different values of the shell thickness: $\mathbf{1}-d_{1}=0 ; \mathbf{2}-d_{1}=3 \mathrm{~nm}$; $3-d_{1}=5 \mathrm{~nm} ; \mathbf{4}-d_{1}=8 \mathrm{~nm}$

Such dependences are also monotonically decreasing. The presence of a two-layer shell in the QD leads to a slight additional reduction in the natural frequencies of acoustic oscillations.

More significant is the effect of changing the thickness of the inner layer of the shell (Fig. 3, curves 3 and 4). It should be noted that the change in the natural frequencies of acoustic oscillations with a change in the radius of the $\mathrm{QD}$ core $R_{0}$ in the case of the multilayer shell (Fig. 3) is smaller than for the single-layer shell (Fig. 2). This effect is positive, since in the presence of an array of QDs with a certain size dispersion, the multilayer shell reduces the dispersion of physical parameters, including reducing the dispersion of natural frequencies of acoustic oscillations.

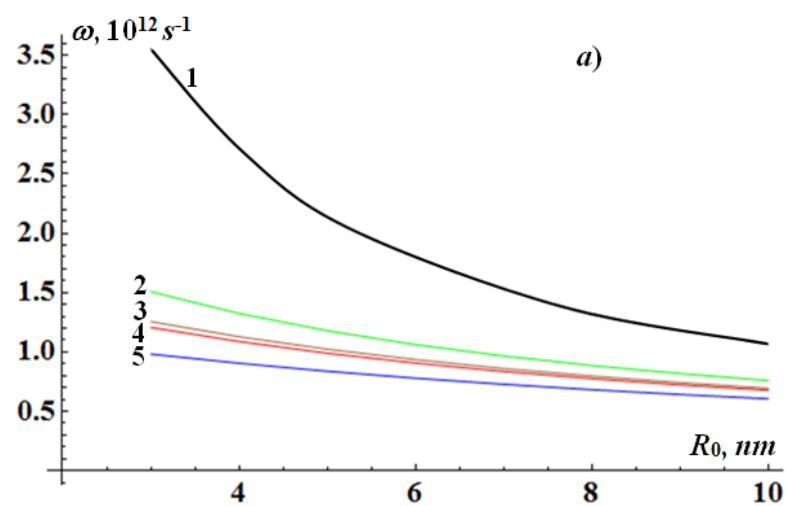




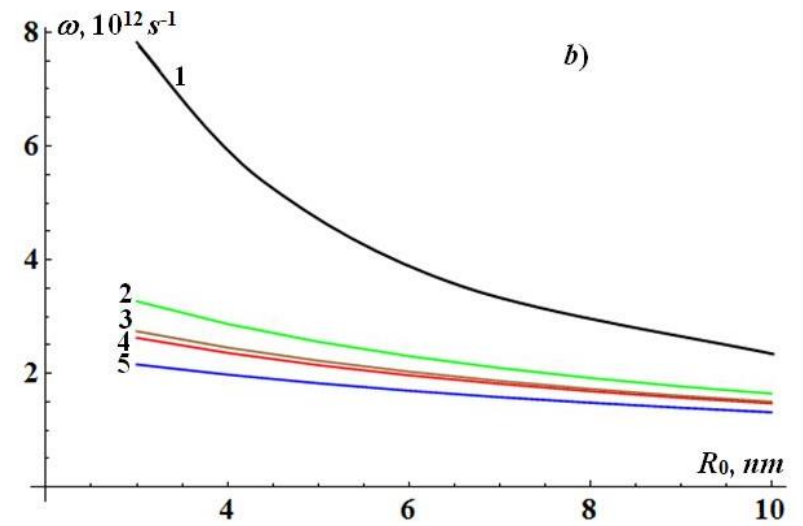

Fig. 3 - The dependences of the natural frequencies of acoustic oscillations of a QD of the type of InAs core/GaAs/ $\mathrm{In}_{0.4} \mathrm{Ga}_{0.6} \mathrm{As}$ shell on the radius of the QD core for the 0th (a) and 1st (b) modes for different thicknesses of the shell layers: $\mathbf{1}-d_{1}=d_{2}=0 ; \quad \mathbf{2}-d_{1}=3 \mathrm{~nm}, \quad d_{2}=2 \mathrm{~nm} ; \quad \mathbf{3}-d_{1}=2 \mathrm{~nm}$, $d_{2}=5 \mathrm{~nm} ; \mathbf{4}-d_{1}=5 \mathrm{~nm}, d_{2}=2 \mathrm{~nm} ; \mathbf{5}-d_{1}=2 \mathrm{~nm}, d_{2}=8 \mathrm{~nm}$

A significant decrease in the natural frequencies at small sizes of the QD core and individual shell layers is due to a decrease in the values of elastic constants in the shell nanolayers and QD core with a decrease in their sizes (for example, at a thickness of $d=2 \mathrm{~nm}$, Young's modulus of GaAs decreases by $27 \%$ ). It can be assumed that for some materials the dependence of the frequency of acoustic oscillations of QDs of the core/ multilayer shell type on the QD size will have a nonmonotonic dependence with a maximum at a certain value of the core radius. This is possible when the dependence of the velocities of sound on the thickness of the nanolayers will be more significant.

\section{CONCLUSIONS}

A model of a QD of the core/multilayer shell type was constructed, within which the spectrum of acoustic oscillations depending on the sizes of the core and individual layers of a shell was determined. It is established that an increase in the number of shell layers leads to a decrease in the natural frequencies of acoustic oscillations of the core/multilayer shell nanoheterosystem. It is shown that an increase in the number of shell layers leads to a decrease in the degree of correlation between the frequencies of acoustic oscillations and the radius of the QD core. The obtained theoretical calculations are in good agreement with the experimental data of works $[17,18]$, where the research results of Raman scattering in the core/shell QD are presented.

An important area of using the developed model can be the production of nanoclusters under the influence of pulsed laser radiation or the use of an array of QDs as a structural unit of solar cells. In [11], it was found that nanoclusters in a transparent dielectric matrix generate sound under the action of electromagnetic radiation. Therefore, to reduce the dispersion of physical parameters of nanosystems with QDs, it is important to have information about the dependence of the frequency of the generated sound on the sizes of the core and shell of QDs.

Fluorescent core/shell semiconductor QDs have been widely used in cancer diagnosis and drug delivery to cancer cells [7]. Carrying out ultrasound diagnostics in such conditions requires accurate information about the spectrum of acoustic oscillations of QDs and the dependence of the amplitude of acoustic deformation on frequency.

The obtained results are important for studying the conditions for the formation of QDs under the influence of ultrasound. For example, in work [19], the thioglycerol-capped CdTe nanocrystals were used as a core template to generate core/shell $\mathrm{CdTe} / \mathrm{CdS}$ nanocrystals in an aqueous solution by means of ultrasonic irradiation. The photoluminescence quantum yields of core/ shell $\mathrm{CdTe} / \mathrm{CdS}$ nanocrystals were up to $20 \%$, which is about 10 times higher than those of the original $\mathrm{CdTe}$ nanocrystals. To investigate the influence of ultrasound on the conditions for the formation of QDs [20], information about the natural frequencies of acoustic oscillations of the studied nanosystems is important.

\section{REFERENCES}

1. E. Sadeghi, Physica E 73, 1 (2015).

2. W. Yang, B. Zhang, N. Ding, W. Ding, L. Wang, M. Yu, Q. Zhang, Ultrasonic. Sonochem. 30, 103 (2016).

3. M.V. Maximov, Yu.M. Shernyakov, F.I. Zubov, A.E. Zhukov, Semicond. Sci. Technol. 28, 105016 (2013).

4. G.S. Selopal, H. Zhao, Zh.M. Wang, Adv. Funct. Mater. 30, $1908762(2020)$.

5. D. Vasudevan, R.R. Gaddam, A. Trinchic, I. Colec, J. Alloy. Compd. 636, 395 (2015).

6. J. Zhang, H. Gu, Dalton Trans. 49, 6119 (2020).

7. P.A. Linkov, K.V. Vokhmintcev, P.S. Samokhvalov, M. LaronzeCochard, J. Sapi, I.R. Nabiev, JETP Let. 107, 233 (2018).

8. A. Valizadeh, H. Mikaeili, M. Samiei, S.M. Farkhani, N. Zarghami, M. Kouhi, A. Akbarzadeh, S. Davaran, $\mathrm{Na}$ noscale Res. Lett. 7, 480 (2012).

9. R.M. Peleshchak, O.V. Kuzyk, O.O. Dan'kiv, Rom. J. Phys. 65, 610 (2020).

10. R.M. Peleshchak, O.V. Kuzyk, O.O. Dan'kiv, J. NanoElectron. Phys. 8, 02014 (2016).

11. N.I. Grigorchuk, P.M. Tomchuk, Eur. Phys. J. B 80, 371 (2011).

12. R.M. Peleshchak, O.V. Kuzyk, O.O. Dan'kiv, S.K. Guba, Cond. Mat. Phys. 22, 13801 (2019).

13. R.M. Peleshchak, O.V. Kuzyk, O.O. Dan'kiv, Physica E 119, 113988 (2020).

14. H. Suzura, T. Ando, Phys. Rev. B 65, 235412 (2002).

15. M. Mazouchi1, M. Dutta, M.A. Stroscio, J. Appl. Phys. 121, 174304 (2017).

16. M.N. Magomedov, Tech. Phys. 59, 1658 (2014).

17. Liu Lu, Xiao-Liang Xu, Wen-Tao Liang Hai-Fei Lu, J. Phys.: Condens. Matter 19406221 (2007).

18. A.G. Milekhin, N.A. Yeryukov, L.L. Sveshnikova, T.A. Duda, C. Himcinschi, E.I. Zenkevich, D.R.T. Zahn, Appl. Phys. A 107, 275 (2012).

19. Ch. Wang, H. Zhang, J. Zhang, M. Li, H. Sun, B. Yang, J. Phys. Chem. C 111, 2465 (2007).

20. R.M. Peleshchak, O.V. Kuzyk, O.O. Dan'kiv, Ukr. J. Phys. 61, 741 (2016). 


\title{
Спектр власних частот акустичних коливань сферичної квантової точки з багатошаровою оболонкою
}

\author{
Р.М. Пелещак ${ }^{1,2}$, О.В. Кузик ${ }^{1}$ О.О. Даньків ${ }^{1}$
}

1 Дрогобицький державний педагогічний університет ілені Івана Франка, вул. Івана Франка, 24, 82100 Дрогобич, Україна

${ }^{2}$ Національний університет “Львівська політехніка”, вул. Степана Бандери, 12, 79013 Львів, Украӥна

Розроблено модель, яка дозволяе визначати спектр акустичних коливань сферичної квантової точки (КТ) виду ядро/багатошарова оболонка у межах пружного континууму. Запропонована модель враховуе залежність пружних сталих (швидкостей акустичних хвиль) від геометричних розмірів ядра КТ та окремих шарів її оболонки. У межах розробленої моделі розраховано спектр акустичних коливань для КТ виду ядро InAs з одношаровою оболонкою GaAs та двошаровою оболонкою $\mathrm{GaAs} / \mathrm{In}_{0.4} \mathrm{Ga}_{0.6} \mathrm{As}$. Встановлено, що наявність оболонки в КТ призводить до суттевого зменшення власних частот акустичних коливань. Показано, що збільшення кількості наношарів оболонки призводить до зменшення ступеня кореляції між частотами акустичних коливань та радіусом ядра КТ. Це пояснюеться тим, що частоти коливань в основному визначаються двома конкуруючими факторами: залежністю частоти коливань від радіуса КТ та залежністю швидкостей поширення поздовжніх і поперечних коливань в тонких шарах від їх товщин. Перший фактор сприяе зменшенню частоти із збільшенням радіуса КТ, а другий - зменшенню частоти при зменшенні кількості атомів у наношарах (зменшенні їх товщини).

Ключові слова: Квантова точка виду ядро/оболонка, Акустична хвиля, Частота акустичних коливань, Деформація. 